\title{
Enterococcus lactis sp. nov., from Italian raw milk cheeses
}

\author{
Stefano Morandi, ${ }^{1}$ Paola Cremonesi, ${ }^{2}$ Milena Povolo ${ }^{3}$ and Milena Brasca ${ }^{1}$ \\ ${ }^{1}$ Institute of Sciences of Food Production, Italian National Research Council (CNR ISPA), \\ Via Celoria 2, 20133 Milan, Italy \\ ${ }^{2}$ Institute of Agricultural Biology and Biotechnology, Italian National Research Council (CNR IBBA), \\ Via Bassini 15, 20133 Milan, Italy \\ ${ }^{3}$ CRA, Fodder and Dairy Productions Research Centre, Via A. Lombardo 11, 26900 Lodi, Italy
}

Correspondence

Milena Brasca

milena.brasca@cnr.it
Enterococci belong to a group of organisms known as lactic acid bacteria and large numbers are usually present in vegetables, plant material and foodstuffs, especially those of animal origin such as dairy products (Giraffa, 2003; Fisher \& Phillips, 2009). Studies on the microbiota of traditional cheeses of Mediterranean countries, produced mainly from raw milk from sheep, goats or cows, indicate that enterococci are a relevant component of the natural cultures involved in fermentation and that they play an important role in cheese ripening, hence contributing to the cheeses' typical taste and flavour (Foulquié Moreno et al., 2006). In addition, enterococci are also used to extend the shelf life and improve the hygienic safety of foodstuffs because they produce antimicrobial substances such as lactic acid, hydrogen peroxide and bacteriocins (enterocins). Bacteriocins have become of great interest as they are frequently active against several Gram-positive, food-borne pathogens such as Listeria monocytogenes, Staphylococcus aureus and Clostridium botulinum and it has been suggested that they should be used as biopreservatives in foods (Franz et al., 2007). Enterococci have also been investigated for their potential as probiotics, a role that is still controversial as some strains

Abbreviations: ITS, intergenic transcribed spacer; RAPD, randomly amplified polymorphic DNA.

The GenBank/EMBL/DDBJ accession number for the 16S rRNA gene sequence of strain BT159 ${ }^{\top}$ is GU983697.

A supplementary figure is available with the online version of this paper. isolated from foods and human samples have been associated with human infections, several virulence factors and antibiotic resistance including resistance to glycopeptide antibiotics (vancomycin) (Foulquié Moreno et al., 2006).

Since the revival of the genus Enterococcus by Schleifer \& Kilpper-Bälz (1984), phylogenetic studies based on $16 \mathrm{~S}$ rRNA gene sequences have established the presence of some species groups, namely 'faecium', 'faecalis', 'avium', 'gallinarum' and a fifth group comprising Enterococcus columbae and Enterococcus cecorum. Other described enterococci form individual lines of descent (Devriese et al., 1993; Devriese \& Pot, 1995; Stiles \& Holzapfel, 1997; Fortina et al., 2004; Fisher \& Phillips, 2009). To date, more than 30 species have been added to the genus Enterococcus on the basis of phylogenetic evidence. Phenotypically, no definite characteristics distinguish enterococci unequivocally from other Gram-positive, catalase-negative, coccus-shaped bacteria or within the genus at the species level. Thus, it is desirable to use a polyphasic approach to correctly identify 'unusual' enterococcal strains (Fortina et al., 2004).

During a study on the autochthonous microflora of an Italian raw milk cheese (Bitto), we isolated some atypical Enterococcus strains that appeared to represent a novel species of the genus Enterococcus (Morandi et al., 2011). Similar strains had been observed a few years ago in sour milk products in Stavropol' Krai (Botina \& Sukhodolets, 2006) but our present paper describes 10 strains isolated 
from Bitto cheese; results of our polyphasic study indicate that these 10 strains represent a novel species.

Strains BT159 ${ }^{\mathrm{T}}$, BT160, BT161, BT171, BT188, BT190, BT204, BT218, BT219 and BT220 were isolated from cheese samples using M17 agar, de Man Rogosa and Sharpe (MRS) agar and kanamycin aesculin azide (KAA) agar (Scharlau Microbiology). They were routinely maintained at $4{ }^{\circ} \mathrm{C}$ after growth at $37{ }^{\circ} \mathrm{C}$ for $18 \mathrm{~h}$ in $\mathrm{M} 17$ broth (Scharlau Microbiology). Cell morphology, Gram staining, catalase activity, hydrolysis of aesculin and production of gas from glucose were tested as reported by Morandi et al. (2011). The effects of temperature $\left(10-45^{\circ} \mathrm{C}\right)$, initial $\mathrm{pH}$ (pH 9.6) and $\mathrm{NaCl}$ concentration $(2,4$ and $6.5 \%$ ) were determined in M17 broth. Moreover, growth on KAA agar, haemolysis on defibrinated sheep blood agar (Merck) and growth in litmus milk were determined. Lipolytic activity on tributyrin agar and hydrolysis of gelatin were tested as reported by Morandi et al. (2006) and Harrigan (1998), respectively. Biochemical tests were also performed using the API 20 STREP and API 50 CHL systems (bioMérieux), according to the manufacturer's instructions. Acid production was determined using bromocresol purple $(0.002 \%, \mathrm{w} / \mathrm{v})$ in $1 \%(\mathrm{w} / \mathrm{v})$ peptone water as indicator. Susceptibility to vancomycin was evaluated by the discdiffusion method on Mueller-Hinton agar (Biolife) with antibiotic discs containing $30 \mu \mathrm{g}$ vancomycin (Oxoid), according to the Clinical and Laboratory Standards Institute (CLSI, 2007).

DNA was isolated and purified using the method of Cremonesi et al. (2006). PCR amplification of $16 \mathrm{~S}$ rRNA was obtained as reported by Edwards et al. (1989). Multilocus sequence analysis based on partial sequences for genes encoding the phenylalanyl-tRNA synthase alpha subunit (pheS) and the RNA polymerase alpha subunit ( $r p o A)$ were detected as described by Naser et al. (2005). Sequencing of the 16S rRNA gene, rpoA and pheS was provided by the sequencing service of Primms (Milan, Italy) as previously described (Morandi et al., 2011). Sequence similarity searches were performed using BLAST in the GenBank database. The sequence information was then imported into CLUSTAL $\mathrm{W}$ version 2 for assembly and alignment. The 16S rRNA gene, rpoA and pheS sequences of strain $\mathrm{BT} 159^{\mathrm{T}}$ were compared with those of the most closely related species retrieved from GenBank. Amplification of the 16S-23S rRNA intergenic transcribed spacer (ITS) was performed as reported by Jensen et al. (1993). The PCR products were quantified using a BioAnalyser 2100 applied to the DNA 1000 LabChip kit (Agilent Technologies). Randomly amplified polymorphic DNA (RAPD) analysis was carried out using primers M13, D11344 and D8635 and conditions as previously described (Andrighetto et al., 2002; Morandi et al., 2006). Grouping of the RAPD-PCR patterns was obtained with BioNumerics version 5.0 (Applied Maths) using cluster analysis with unweighted pair group method using arithmetic averages; the value for repeatability of the RAPD-PCR assay, DNA extraction and running conditions was $90 \%$.
Cellular fatty acid composition was determined according to the procedure of Miller \& Berger (1985). The MIDI protocol for standardization of the physiological age of cells was applied (http://www.microbialid.com/PDF/TechNote_ 101.pdf). About $40 \mathrm{mg}$ bacterial cells were saponified with $1 \mathrm{ml}$ basic methanol (45 g NaOH dissolved in $300 \mathrm{ml}$ deionized water: methanol, $1 / 1, \mathrm{v} / \mathrm{v}$ ); tubes containing the saponified mixture were vortexed for 5-10 $\mathrm{s}$ and kept in a boiling water bath for $30 \mathrm{~min}$. After cooling to room temperature, $2 \mathrm{ml} 6 \mathrm{M} \mathrm{HCl} /$ methanol $(325: 275$, v/v) was added and the sample was heated in an $80{ }^{\circ} \mathrm{C}$ water bath for $10 \mathrm{~min}$. The sample was cooled rapidly, $1.25 \mathrm{ml}$ methyl tertbutyl ether/hexane $(1: 1, \mathrm{v} / \mathrm{v})$ was added and the tube was turned end over end for about $10 \mathrm{~min}$. The lower aqueous phase was discarded by pipetting, $3 \mathrm{ml} 0.3 \mathrm{M} \mathrm{NaOH}$ was added and the tube was turned end over end for $5 \mathrm{~min}$. Then, the organic phase was transferred into a $2 \mathrm{ml}$ glass vial. Fatty acid methyl ester analysis was performed using a HP 6890 series GC (Agilent) equipped with a Supelcowax 10 capillary column ( $30 \mathrm{~m}$ length, $0.32 \mathrm{~mm}$ i.d., $0.25 \mu \mathrm{m}$ film thickness; Supelco), a split-splitless injector at $250{ }^{\circ} \mathrm{C}$ and a flame-ionization detector at $250{ }^{\circ} \mathrm{C}$. One microlitre was injected in splitless mode. Hydrogen was used as the carrier gas at a constant flow of $1 \mathrm{ml} \mathrm{min}{ }^{-1}$. The oven temperature was held at $40{ }^{\circ} \mathrm{C}$ for $4 \mathrm{~min}$, increased to $150{ }^{\circ} \mathrm{C}$ at a rate of $25{ }^{\circ} \mathrm{C} \mathrm{min}{ }^{-1}$, held at $150{ }^{\circ} \mathrm{C}$ for $1 \mathrm{~min}$, increased to $220{ }^{\circ} \mathrm{C}$ at a rate of $4{ }^{\circ} \mathrm{C} \mathrm{min}{ }^{-1}$ and held at $220{ }^{\circ} \mathrm{C}$ for $5 \mathrm{~min}$. Identification of individual fatty acid methyl esters was performed by analysing both the certified reference material CRM 164 (Commission of the European Communities, 1993) and the Bacterial Acid Methyl Esters standard mixture (Supelco). Values were expressed as relative percentages of the total fatty acid content.

The isolates were Gram-positive, spherical or ovoid cells occurring in pairs or short chains, catalase-negative, nonmotile and non-endospore-forming. The isolates grew on KAA agar, showed $\beta$-haemolysis on defibrinated sheep blood and were able to grow in litmus milk, in which they caused reduction and clotting within $24 \mathrm{~h}$ of incubation. All of the isolates were susceptible to vancomycin. Growth occurred at 10 and $45{ }^{\circ} \mathrm{C}$ and $\mathrm{pH}$ 9.6. The isolates grew in M17 broth containing $6.5 \% \mathrm{NaCl}$, which is in accordance with the genus Enterococcus. The species description gives a detailed description of other characteristics. Biochemical tests useful for differentiating the novel isolates from other enterococci are given in Table 1.

The almost-complete 16S rRNA gene sequence of strain BT $159^{\mathrm{T}}$ obtained in this study (1437 bp) indicated that the isolate belonged to the genus Enterococcus and was closely related to Enterococcus hirae ATCC $8043^{\mathrm{T}}$ (98.8\%), Enterococcus durans CECT $411^{\mathrm{T}}(98.9 \%)$ and Enterococcus faecium ATCC $19434^{\mathrm{T}}(99.4 \%)$. Lower sequence similarities $(<98.5 \%)$ were found with other recognized species of the genus Enterococcus. Strain BT159 ${ }^{\mathrm{T}}$ belonged to the E. faecium species group, comprising E. faecium, E. durans, E. hirae, Enterococcus mundtii and Enterococcus villorum. The multilocus sequence analysis based on rpoA and pheS for the 
Table 1. Biochemical tests useful for the differentiation of Enterococcus lactis sp. nov. from other enterococci

Taxa: 1, Enterococcus lactis sp. nov.; 2, E. durans; 3, E. faecalis; 4, E. faecium; 5, E. gilvus; 6, E. italicus; 7, E. hirae; 8, E. casseliflavus; 9, E. mundtii. Data for columns 2-9 were taken from Collins et al. (1984, 1986), Farrow \& Collins (1985), Tyrrell et al. (2002), Klein (2003), Fortina et al. (2004) and Tanasupawat et al. (2008). All taxa are positive for acid production from lactose. + , Positive with rare exceptions; w, weakly positive; $\mathrm{v}$, variable; -, negative with rare exceptions; NR, not reported.

\begin{tabular}{|c|c|c|c|c|c|c|c|c|c|}
\hline Characteristic & 1 & 2 & 3 & 4 & 5 & 6 & 7 & 8 & 9 \\
\hline \multicolumn{10}{|l|}{ Growth at/with: } \\
\hline $10{ }^{\circ} \mathrm{C}$ & + & + & + & + & + & $\mathrm{w}$ & + & $\mathrm{w}$ & + \\
\hline $45^{\circ} \mathrm{C}$ & + & + & + & + & + & $\mathrm{V}$ & + & + & + \\
\hline $6.5 \% \mathrm{NaCl}$ & + & + & + & + & + & - & + & + & + \\
\hline \multicolumn{10}{|c|}{ Acid production from: } \\
\hline L-Arabinose & + & - & - & + & + & - & - & + & + \\
\hline Glycerol & - & - & + & + & + & - & - & - & $\mathrm{v}$ \\
\hline Mannitol & + & - & + & + & + & $\mathrm{V}$ & - & + & + \\
\hline Melibiose & + & - & - & $\mathrm{V}$ & + & - & + & + & + \\
\hline Melezitose & - & - & + & - & NR & - & $\mathrm{V}$ & - & - \\
\hline Raffinose & - & - & - & - & + & - & + & V & + \\
\hline Ribose & + & + & + & + & + & - & + & + & + \\
\hline Salicin & + & + & + & + & + & + & - & + & + \\
\hline Sorbitol & - & - & + & $\mathrm{V}$ & + & $\mathrm{V}$ & - & - & $\mathrm{V}$ \\
\hline Sucrose & - & - & + & $\mathrm{V}$ & + & + & + & + & + \\
\hline Xylose & - & - & - & - & - & - & - & + & + \\
\hline
\end{tabular}

identification of Enterococcus species (Naser et al., 2006) confirmed the separation of strain BT $159^{\mathrm{T}}$ from species of the genus Enterococcus. The sequences of rpoA (675 bp) and
pheS (455 bp) of strain $\mathrm{BT} 159^{\mathrm{T}}$ showed 98 and $95 \%$ similarity, respectively, with E. faecium LMG 16198. The isolates produced a characteristic 16S-23S rRNA ITS pattern compared with other members of the genus Enterococcus (Fig. 1). The isolates demonstrated genetic homogeneity and were separated from the reference strains by the presence of six bands of 1288, 588, 555, 490, 315 and $250 \mathrm{bp}$. Moreover, the RAPD-PCR analysis indicated a distinct clustering of the 10 isolates (coefficient similarity $25 \%$; Fig. S1, available in IJSEM Online).

The fatty acid composition of the isolates was compared with those of the type strains of E. faecium and E. durans, their closest phylogenetic neighbours. The major fatty acids of the isolates were $\mathrm{C}_{16: 0}(30.0 \%), \mathrm{C}_{19: 0}$ cyclo $9 c(20.3 \%)$, $\mathrm{C}_{18: 1}(17.5 \%), \mathrm{C}_{16: 1}(15.4 \%)$ and $\mathrm{C}_{14: 0}(10.4 \%)$. In addition, small amounts of $\mathrm{C}_{17: 0}$ cyclo $(2.2 \%)$ and $\mathrm{C}_{18: 0}$ $(0.8 \%)$ were found. E. faecium contained the same fatty acids but with some quantitative differences: smaller amounts of $\mathrm{C}_{16: 0}(23.7 \%)$ and $\mathrm{C}_{17: 0}$ cyclo (1.4\%) and a larger amount of $\mathrm{C}_{19: 0}$ cyclo $9 c(26.6 \%)$. E. durans contained smaller amounts of $\mathrm{C}_{16: 1}(10.5 \%), \mathrm{C}_{14: 0}(9.1 \%)$ and $\mathrm{C}_{17: 0}$ cyclo $(0.6 \%)$ and a larger amount of $\mathrm{C}_{18: 0}(2.3 \%)$; moreover, $E$. durans showed the presence of small amounts of odd-numbered and branched-chain fatty acids that were not found in the isolates.

All of the data from the present study suggest that the isolates should be assigned to a novel species of the genus Enterococcus, for which we propose the name Enterococcus lactis sp. nov.

\section{Description of Enterococcus lactis sp. nov.}

Enterococcus lactis (lac'tis. L. gen. n. lactis from milk, referring to dairy products, from which the species was first isolated).

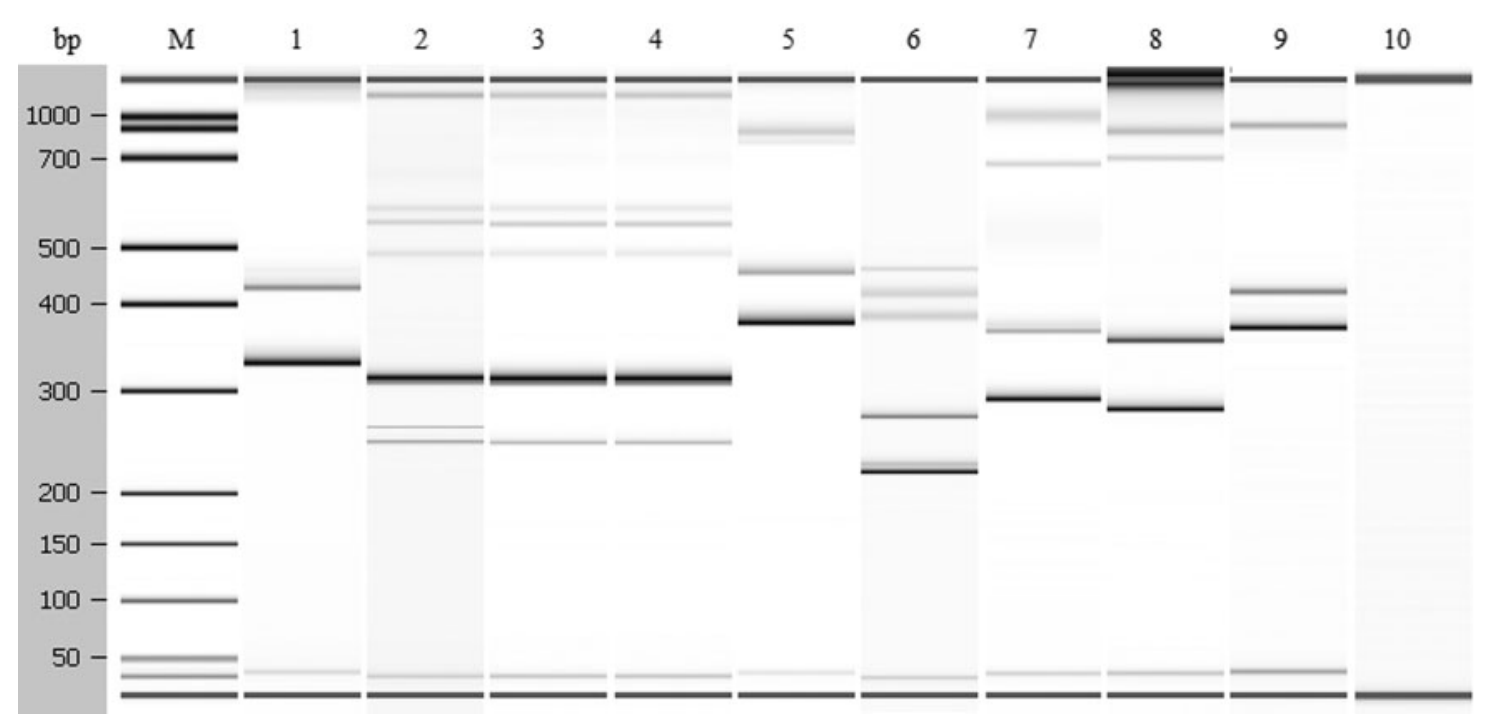

Fig. 1. ITS analysis of Enterococcus lactis sp. nov. and other enterococcal species. Lanes: M, DNA ladder (DNA 500 LabChip Kit; Agilent Technologies); 1, Enterococcus hirae ATCC 8043 ${ }^{\top} ; 2-4$, Enterococcus lactis sp. nov. (BT504, BT159 ${ }^{\top}$, BT161);

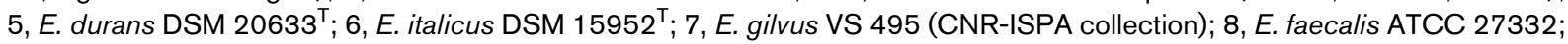
9, E. faecium DSM $20477^{\top} ; 10$, negative control. 
The description is based on 10 strains. Cells are Grampositive, facultatively anaerobic, non-motile, non-sporeforming, spherical and arranged in pairs or short chains. On M17, MRS and blood agar, colonies are whitish, smooth and circular with entire margins, whereas on KAA agar, colonies are typical of presumptive enterococci (surrounded by a black halo). Grows with $2.0-6.5 \% \mathrm{NaCl}$, at $10-45{ }^{\circ} \mathrm{C}$ and at $\mathrm{pH} 9.6$. Positive for hydrolysis of aesculin and negative for catalase, hydrolysis of gelatin and tributyrin, and production of gas from glucose. In litmus milk, grows and causes acidification, reduction and clotting within $24 \mathrm{~h}$. Shows haemolysis on blood agar $[(\alpha$-haemolysis $(n=8)$ and $\gamma$-haemolysis $(n=2)]$ and is susceptible to vancomycin. Positive for the Voges-Proskauer test and leucine aminopeptidase, pyrrolidonyl arylamidase and arginine dihydrolase, but negative for alkaline phosphatase, $\alpha$-galactosidase, $\beta$-glucuronidase and hippurate. $\beta$-Galactosidase activity is strain-dependent. Produces acid from arabinose, arbutin, $N$ acetylglucosamine, cellobiose, $\mathrm{D}$-fructose, galactose, $\beta$-gentiobiose, D-glucose, lactose, maltose, L-mannitol, D-mannose, methyl $\alpha$-D-mannoside, melibiose, ribose, salicin, D-tagatose and trehalose, but not from adonitol, amygdalin, Darabinose, D-arabitol, L-arabitol, dulcitol, erythritol, Dfucose, L-fucose, gluconate, methyl $\alpha$-D-glucoside, glycerol, glycogen, inositol, inulin, 2-ketogluconate, 5-ketogluconate, D-lyxose, melezitose, raffinose, rhamnose, sorbitol, L-sorbose, sucrose, turanose, xylitol, methyl $\beta$-D-xyloside, D-xylose or Lxylose; acid production from starch is weak.

The type strain is BT $159^{\mathrm{T}}\left(=\mathrm{DSM} 23655^{\mathrm{T}}=\mathrm{LMG} 25958^{\mathrm{T}}\right)$, isolated from Bitto cheese, a Protected Designation of Origin (PDO) raw milk cheese produced in a restricted Italian alpine area.

\section{Acknowledgements}

This study was partly performed within the research projects VALTEC and Accordo Quadro CNR-Regione Lombardia supported by the Regione Lombardia.

\section{References}

Andrighetto, C., Borney, F., Barmaz, A., Stefanon, B. \& Lombardi, A. (2002). Genetic diversity of Streptococcus thermophilus strains isolated from Italian traditional cheese. Int Dairy J 12, 141-144.

Botina, S. G. \& Sukhodolets, V. V. (2006). Speciation in bacteria: comparison of the 16S rRNA gene for closely related Enterococcus species. Russ J Genet 42, 247-251.

CLSI (2007). Performance Standards for Antimicrobial Susceptibility Testing, Seventeenth Informational Supplement. M100-S17. Wayne, PA: NCCLS.

Collins, M. D., Jones, D., Farrow, J. A. E., Kilpper-Balz, R. \& Schleifer, K. H. (1984). Enterococcus avium nom. rev., comb. nov.; E. casseliflavus nom. rev., comb. nov.; E. durans nom. rev., comb. nov.; E. gallinarum comb. nov.; and E. malodoratus sp. nov. Int J Syst Bacteriol 34, 220-223.

Collins, M. D., Farrow, J. A. \& Jones, D. (1986). Enterococcus mundtii sp. nov. Int J Syst Bacteriol 36, 8-12.

Commission of the European Communities (1993). Certification of the fatty acid profile and mass fraction of butyric acid ( $n$-butanoic acid), cholesterol and three individual sterols of an anhydrous milk fat reference material with values for information on triglycerides, minor fatty acids, added vanillin and 'total' sterol mass fraction. CRM 164. Report 15277.

Cremonesi, P., Castiglioni, B., Malferrari, G., Biunno, I., Vimercati, C., Moroni, P., Morandi, S. \& Luzzana, M. (2006). Technical note: improved method for rapid DNA extraction of mastitis pathogens directly from milk. J Dairy Sci 89, 163-169.

Devriese, L. A. \& Pot, B. (1995). The genus Enterococcus. In The Genera of Lactic Acid Bacteria, pp. 327-367. Edited by B. J. B. Wood \& W. H. Holzapfel. London: Blackie Academic \& Professional.

Devriese, L. A., Pot, B. \& Collins, M. D. (1993). Phenotypic identification of the genus Enterococcus and differentiation of phylogenetically distinct enterococcal species and species groups. J Appl Bacteriol 75, 399-408.

Edwards, U., Rogall, T., Blöcker, H., Emde, M. \& Böttger, E. C. (1989). Isolation and direct complete nucleotide determination of entire genes. Characterization of a gene coding for $16 \mathrm{~S}$ ribosomal RNA. Nucleic Acids Res 17, 7843-7853.

Farrow, J. A. E. \& Collins, M. D. (1985). Enterococcus hirae, a new species that includes amino acid assay strain NCDO 1258 and strains causing growth depression in young chickens. Int J Syst Bacteriol 35, 73-75.

Fisher, K. \& Phillips, C. (2009). The ecology, epidemiology and virulence of Enterococcus. Microbiology 155, 1749-1757.

Fortina, M. G., Ricci, G., Mora, D. \& Manachini, P. L. (2004). Molecular analysis of artisanal Italian cheeses reveals Enterococcus italicus sp. nov. Int J Syst Evol Microbiol 54, 1717-1721.

Foulquié Moreno, M. R., Sarantinopoulos, P., Tsakalidou, E. \& De Vuyst, L. (2006). The role and application of enterococci in food and health. Int J Food Microbiol 106, 1-24.

Franz, C. M., van Belkum, M. J., Holzapfel, W. H., Abriouel, H. \& Gálvez, A. (2007). Diversity of enterococcal bacteriocins and their grouping in a new classification scheme. FEMS Microbiol Rev 31, 293310.

Giraffa, G. (2003). Functionality of enterococci in dairy products. Int J Food Microbiol 88, 215-222.

Harrigan, W. F. (1998). Reactions involving protein, amino acids and other nitrogen compounds, including tests for proteolytic activity. In Laboratory Methods in Food Microbiology 3rd edn, pp. 100-107. Edited by W. F. Harrigan. London: Academic Press.

Jensen, M. A., Webster, J. A. \& Straus, N. (1993). Rapid identification of bacteria on the basis of polymerase chain reaction-amplified ribosomal DNA spacer polymorphisms. Appl Environ Microbiol 59, 945-952.

Klein, G. (2003). Taxonomy, ecology and antibiotic resistance of enterococci from food and the gastro-intestinal tract. Int J Food Microbiol 88, 123-131.

Miller, L. \& Berger, T. (1985). Bacteria identification by gas chromatography of whole cell fatty acid. Hewlett Packard Application note 228-41, 1-8.

Morandi, S., Brasca, M., Andrighetto, C., Lombardi, A. \& Lodi, R. (2006). Technological and molecular characterisation of enterococci isolated from north-west Italian dairy products. Int Dairy J 16, 867875.

Morandi, S., Brasca, M. \& Lodi, R. (2011). Technological, phenotypic and genotypic characterisation of wild lactic acid bacteria involved in the production of Bitto PDO Italian cheese. Dairy Sci Technol 91, 341-359.

Naser, S. M., Thompson, F. L., Hoste, B., Gevers, D., Dawyndt, P., Vancanneyt, M. \& Swings, J. (2005). Application of multilocus 
sequence analysis (MLSA) for rapid identification of Enterococcus species based on rpoA and pheS genes. Microbiology 151, 2141-2150.

Naser, S. M., Vancanneyt, M., Hoste, B., Snauwaert, C., Vandemeulebroecke, K. \& Swings, J. (2006). Reclassification of Enterococcus flavescens Pompei et al. 1992 as a later synonym of Enterococcus casseliflavus (ex Vaughan et al. 1979) Collins et al. 1984 and Enterococcus saccharominimus Vancanneyt et al. 2004 as a later synonym of Enterococcus italicus Fortina et al. 2004. Int J Syst Evol Microbiol 56, 413-416.

Schleifer, K. H. \& Kilpper-Bälz, R. (1984). Transfer of Streptococcus faecalis and Streptococcus faecium to the genus Enterococcus nom. rev. as Enterococcus faecalis comb. nov. and Enterococcus faecium comb. nov. Int J Syst Bacteriol 34, 31-34.

Stiles, M. E. \& Holzapfel, W. H. (1997). Lactic acid bacteria of foods and their current taxonomy. Int J Food Microbiol 36, 1-29.

Tanasupawat, S., Sukontasing, S. \& Lee, J. S. (2008). Enterococcus thailandicus sp. nov., isolated from fermented sausage ('mum') in Thailand. Int J Syst Evol Microbiol 58, 1630-1634.

Tyrrell, G. J., Turnbull, L. A., Teixeira, L. M., Lefebvre, J., Carvalho, M. G., Facklam, R. R. \& Lovgren, M. (2002). Enterococcus gilvus sp. nov. and Enterococcus pallens sp. nov. isolated from human clinical specimens. J Clin Microbiol 40, 1140-1145. 